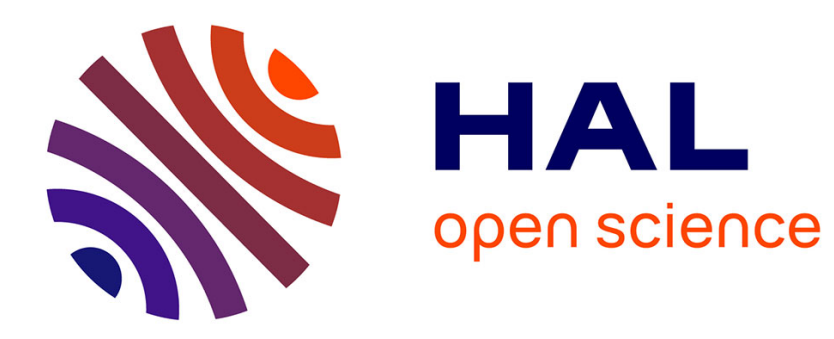

\title{
NON EXPLOSIVE COLLAPSE OF A WHITE DWARF
}

R. Mochkovitch

\section{To cite this version:}

R. Mochkovitch. NON EXPLOSIVE COLLAPSE OF A WHITE DWARF. Journal de Physique Colloques, 1980, 41 (C2), pp.C2-153-C2-153. 10.1051/jphyscol:1980224 . jpa-00219816

\section{HAL Id: jpa-00219816 https://hal.science/jpa-00219816}

Submitted on 1 Jan 1980

HAL is a multi-disciplinary open access archive for the deposit and dissemination of scientific research documents, whether they are published or not. The documents may come from teaching and research institutions in France or abroad, or from public or private research centers.
L'archive ouverte pluridisciplinaire HAL, est destinée au dépôt et à la diffusion de documents scientifiques de niveau recherche, publiés ou non, émanant des établissements d'enseignement et de recherche français ou étrangers, des laboratoires publics ou privés. 


\section{NON EXPLOSIVE COLLAPSE OF A WHITE DWARF}

R. Mochkovitch

Observatoire de Meudon

Résumé.- L'accrétion de matière sur une naine blanche a été proposée comme origine des explosions de novae et de supernovae de type I. I'accrétion suivie d'un effondrement non explosif conduisant à la formation d'une étoile à neutrons $n$ 'est possible que si certaines contraintes sur la composition ou la structure de la naine blanche, sur le taux d'accrétion, ou sur le taux de production d'énergie par les réactions nucléaires sont respectées. Une présentation détaillée de ces contraintes sera donnée.

Abstract.- Matter accretion on a white dwarf has been proposed to explain the novae and type I supernovae explosions. Accretion followed by a non explosive collapse, and leading to the formation of a neutron star is possible only if some constraints on the composition or the structure of the white dwarf, on the accretion rate, or on the energy production rate by nuclear reactions are respected. A detailed presentation of these constraints will be given. 